\title{
Analisis Kestabilan Transien Dan Mekanisme Pelepasan Beban Di PT. Pusri Akibat Penambahan Generator Dan Penambahan Beban
}

\author{
Baghazta Akbar A, Margo Pujiantara, Daniar Fahmi \\ Jurusan Teknik Elektro, Fakultas Teknologi Industri, Institut Teknologi Sepuluh Nopember (ITS) \\ Jl. Arief Rahman Hakim, Surabaya - 60111 Indonesia \\ e-mail:margo@ee.its.ac.id, daniar.fahmi@ee.its.ac.id
}

\begin{abstract}
Abstrak - PT. Pusri Palembang adalah perusahaan yang didirikan sebagai produsen pupuk nasional yang juga bertanggung jawab dalam melaksanakan distribusi dan pemasaran pupuk bersubsisdi untuk mendukung program pangan nasional. Untuk memenuhi kebutuhan produksi PT. Pusri Palembang melakukan penambahan pabrik baru. Maka untuk menjaga kontinuitas sistem kelistrikan yang ada diperlukan penambahan 1 unit pembangkit baru, pada mulanya ada 4 unit pembangkit yang beroperasi menjadi 5 unit pembangkit. Akibat penambahan pabrik baru ini, kestabilan transien pada plant belum dianalisis secara mendalam, sehingga perlu dilakukan studi stabilitas transien untuk mengetahui keandalan sistem saat terjadi gangguan transien. Pada penelitian ini akan dilakukan analisis kestabilan transien akibat generator lepas, motor starting, dan hubung singkat kemudian akan dilakukan perancanggan mekanisme load shedding agar sistem mampu mempertahankan kestabilannya dan kontinuitas aliran daya tetap terjaga. Hasil simulasi menunjukkan bahwa saat salah satu generator outage pada case A dan saat generator P1B atau STG outage pada case B memerlukan mekanisme load shedding. Mekanisme load shedding yang dilakukan menggunakan standar frekuensi. Saat kasus hubung singkat pada bus SG-3301, SG-SB, dan STG_1 memerlukan mekanisme load shedding. Selain itu, kasus motor starting masih diperbolehkan saat 5 generator ON karena tidak memberikan efek yang singnifikan pada respon tegangan, frekuensi, dan sudut rotor pada sistem.
\end{abstract}

Kata Kunci: Gangguan Transien, Kestabilan Transien, Pelepasan Beban.

\section{PENDAHULUAN}

$\mathrm{S}$ EIRING dengan perkembangan sistem tenaga listrik, masalah stabilitas pada sistem tenaga listrik menjadi hal yang utama untuk menjamin kontinuitas dan keandalan operasi dari suatu sistem tenaga listrik. Perkembangan sistem tenaga listrik baik pada beban maupun generator akan secara otomatis menimbulkan masalah-masalah baru yang menyangkut tentang masalah kestabilan sistem. Dalam suatu sistem atau plant yang besar, lebih dari dua generator yang bekerja secara bersamaan, kerugian besar mungkin dapat terjadi jika kontinuitas daya tidak stabil [1]. Suatu sistem dikatakan stabil ketika terdapat keseimbangan antara daya mekanik pada penggerak utama generator (prime mover) dengan daya output listrik. Daya output listrik sangat dipengaruhi oleh kenaikan dan penurunan beban dimana saat hal tersebut terjadi maka prime mover harus mampu menyesuaikan masukan daya input mekanik yang sesuai. Apabila pada saat yang sama prime mover tidak mampu menyesuaikan dengan kondisi beban, hal ini dapat mengakibatkan sistem menjadi tidak stabil Dalam keadaan setimbang maka generator berputar dengan kecepatan sinkron. Berdasarkan paper IEEE Transactions on Power Systems berjudul Definition and Classification of Power System Stability, kestabilan sistem tenaga listrik dikategorikan menjadi tiga, yaitu kestabilan frekuensi, sudut rotor, dan tegangan [2]. Definisi ini berlaku juga untuk sistem yang beroperasi dengan menginterkoneksikan beberapa generator (multimachine) [3].

Gangguan transien sangat mempengaruhi stabilitas dari suatu sistem kelistrikan pada industri-industri besar sehingga perlu dianalisis lebih lanjut. Setelah dilakukan penambahan generator dan penambahan beban, PT. Pusri Palembang belum melakukan studi transien yang lebih mendalam. Sehingga dibutuhkan studi stabilitas transien untuk mengetahui kestabilan sistem saat terjadi gangguan transien. Berdasarkan paper referensi Definition and Classification of Power System Stability, maka pada penelitian ini dilakukan analisis yang meliputi kestabilan frekuensi, sudut rotor, dan tegangan [2]. Sedangkan perubahan yang akan terjadi pada sistem meliputi generator lepas, motor starting, dan hubung singkat. Pada penelitian ini juga akan dianalisis mekanisme pelepasan beban untuk mengatasi gangguan transien yang terjadi.

\section{KESTABILAN TRANSIEN}

\section{A. Kestabilan Sistem Tenaga}

Sistem tenaga listrik yang kompleks memiliki banyak beban-beban dinamis yang besar daya yang diserapnya sangat variasi dalam rentang waktu tertentu, dengan adanya perubahan ini pasokan daya yang disalurkan oleh generator harus sesuai dengan kebutuhan bebannya. Kestabilan sistem tenaga listrik secara umum dapat didefinisikan sebagai kemampuan dari suatu sistem tenaga listrik untuk mempertahankan keadaan sinkronnya pada saat dan sesudah terjadi gangguan. Definisi ini berlaku juga untuk sistem yang beroperasi dengan menginterkoneksikan beberapa generator (multimachine). Ketika kondisi sistem tidak sinkron perlu dilakukan usaha untuk mengembalikan sistem menjadi sinkron setelah terjadi ganguan. Berdasarkan Paper IEEE definition and classification of power system stability, kestabilan sistem tenaga listrik dibagi menjadi tiga kategori, yaitu : 


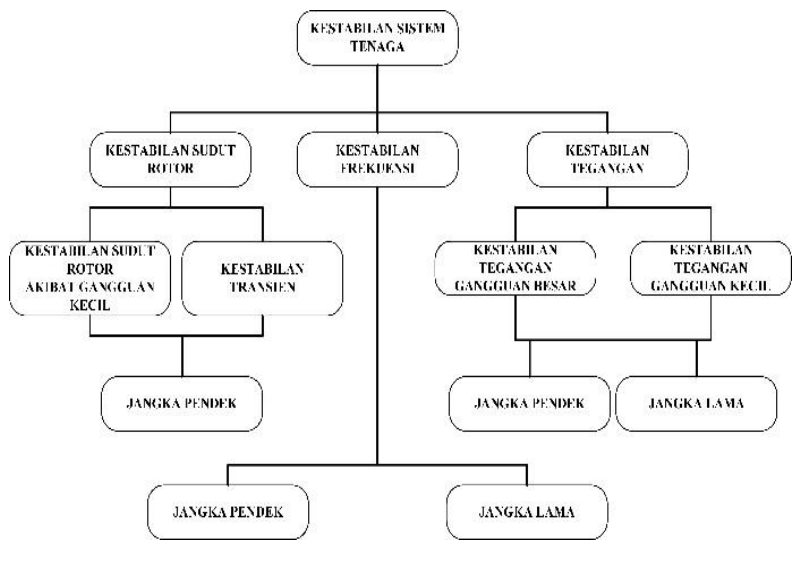

Gambar 1. Klasifikasi Kestabilan SistemTenaga

1. Kestabilan sudut rotor

Kestabilan sudut rotor merupakan kemampuan dari mesin sinkron yang terhubung dengan sistem untuk tetap sinkron setelah terjadi gangguan. Ketidakstabilan akan mengakibatkan naiknya sudut rotor yang berbeda-beda dari generator sehingga dapat mengakibatkan generator mengalami hilang sinkronisasi dengan generator lain [2].

2. Kestabilan frekuensi [1]

Kestabilan frekuensi merupakan kemampuan dari sistem tenaga mempertahankan frekuensi untuk tetap stabil ketika terjadi gangguan dan setelah terjadi gangguan. Biasanya gangguan ini berupa perubahan pembangkit atau bebanyang signifikan.

3. Kestabilan tegangan [1]

Kestabilan tegangan merupakan kemampuan dari sistem tenaga mempertahankan tegangan untuk tetap stabil pada semua bus setelah terjadi gangguan. Hal ini tergantung dari sistem untuk tetap mempertahankan keseimbangan antara suplai daya dan beban.

\section{B. Kestabilan Transien}

Kestabilan transien merupakan kemampuan dari sistem tenaga untuk mempertahankan sinkronisasi ketika mengalami gangguan transien. Gangguan transien ini berupa gangguan besar yang terjadi pada sistem seperti gangguan hubung singkat, motor starting, pelepasan beban serta penambahan beban secara tiba-tiba [2].

\section{Standar yang Digunakan untuk Analisis Kestabilan Transien}

Dalam menentukan suatu sistem tenaga listrik stabil atau tidak yaitu dengan mengevaluasi respon tegangan dan frekuensi sistem. Standart yang dipakai untuk menentukan sistem stabil atau tidak yaitu :

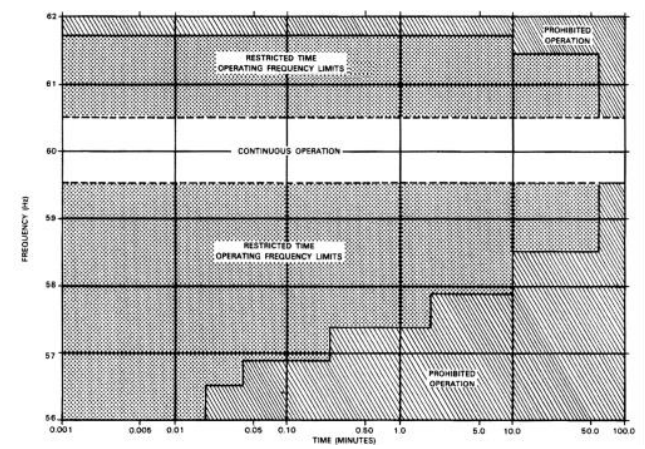

Gambar 2. Standar Frekuensi untuk Steam Turbin Generator (IEEEStdC37.106-2003)

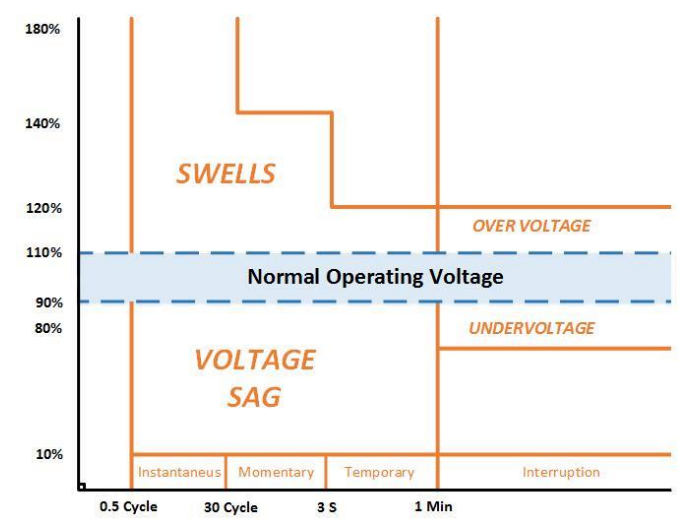

Gambar 3. Definisi Voltage Magnitude Event berdasarkan Standar IEEE 1195-1995

\section{Pelepasan Beban}

Pelepasan beban merupakan salah satu langkah untuk mempertahankan kestabilan. Jika terjadi gangguan seperti generator outage mengakibatkan daya yang tersedia tidak mampu melayani beban, sehingga untuk menjaga sistem tidak black out maka diperlukan pelepasan beban.

Ketika beban dalam kondisi kekurangan suplai daya, tidak dijinkan melepas beban secara besar-besaran. Terdapat dua skema pelepasan beban yang mengacu pada standar ANSI/IEEE C37.106-1987 [4], yaitu pelepasan beban tiga langkah dan pelepasan beban enam langkah.

\section{SISTEM KELISTRIKAN PT. PUSRI PALEMBANG}

PT Pusri Palembang mempunyai sistem kelistrikan yang besar dan kompleks. Pada kondisi awal sebelum diberi penambahan beban dan generator baru, PT Pusri Palembang memiliki tiga unit pembangkit dengan kapasitas $15 \mathrm{MW}$ dan satu unit pembangkit dengan kapasitas 22,6 MW. Sistem kelistrikan di PT Pusri Palembang merupakan sistem kelistrikan islanding, yang saling terhubung dengan synchronous bus untuk menjaga keandalan dari sistem kelistrikan PT Pusri Palembang. Islanding tersebut terbagi atas Pusri 2, Pusri 3, Pusri 4, dan Pusri 1B.

Penambahan beban berupa Pusri 2B serta pembangkit STG-1 yang berkapasitas $38 \mathrm{MW}$ membuat perubahan sistem kelistrikan pada PT PUSRI sehingga membutuhkan penambahan synchronous bus baru dengan kapasitas $33 \mathrm{kV}$ untuk menghubungkan jaringan baru dan jaringan lama. Powerplant yang semula terbagi atas empat bagian, kini berubah menjadi lima bagian dengan adanya Pusri 2B. Pembangkit STG-1 ini mensuplai daya untuk Pusri 2B dan mengalirkan daya ke jaringan kelistrikan yang lama. 


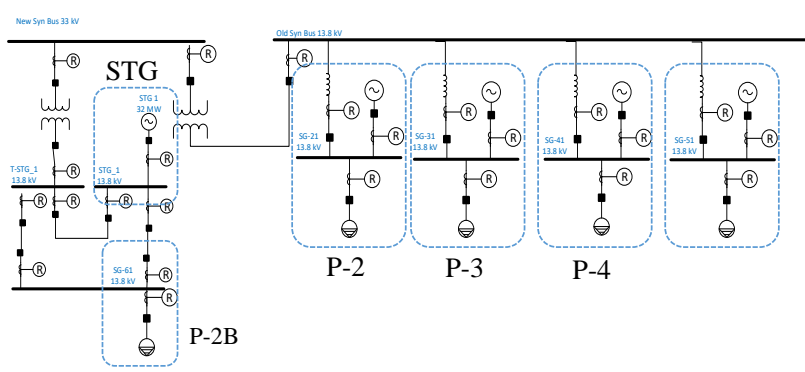

Gambar 2. Sistem Kelistrikan Baru PT. Pusri Palembang

\section{SIMULASI DAN ANALISIS}

A. Studi Kasus Kestabilan Transien

Pada simulasi ini dilakukan analisis kestabilan transien dan mekanisme pelepasan beban di PT. Pusri Palembang akibat generator outage, short circuit, motor starting. Parameter-parameter yang perlu diperhatikan dalam penelitian ini adalah respon dari frekuensi, tegangan, dan sudut rotor pada sistem.

\section{B. Simulasi Generator Outage}

Terdapat 2 case utuk generator outage yaitu case A (saat plant P2B sudah terhubung dengan sitem, pembangkit STG belum) dan case B (saat plant P2B dan pembangkit STG terhubung)

Tabel 1.

Studi kasus generator outage

\begin{tabular}{ll}
\hline \multicolumn{1}{c}{ Kasus } & \multicolumn{1}{c}{ Keterangan } \\
\hline CASE A & Plant P2B terhubung, STG belum \\
Gen P-4 OFF & Generator P-4 outage dari sistem \\
CASE B & Plant P2b dan STG terhubung \\
Gen STG OFF & Generator STG outage dari sistem \\
\hline \hline
\end{tabular}

B.1 Studi kasus CASE A, Gen P-4 off

Pada kasus ini disimulasikan case A (STG belum terhubung) lepasnya generator P-4 dan dilanjutkan mekanisme load shedding.

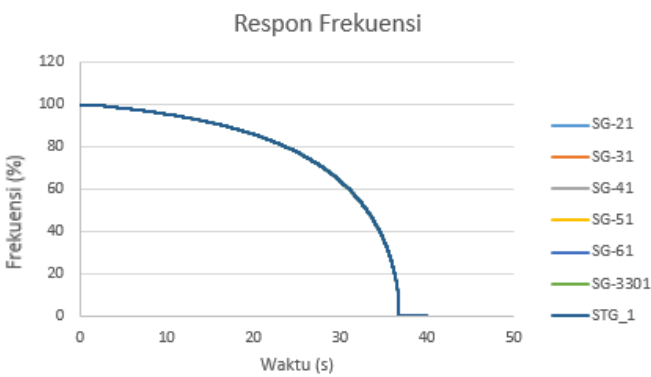

Gambar 3. Respon Frekuensi Saat Generator P-2 Outage dari Sistem

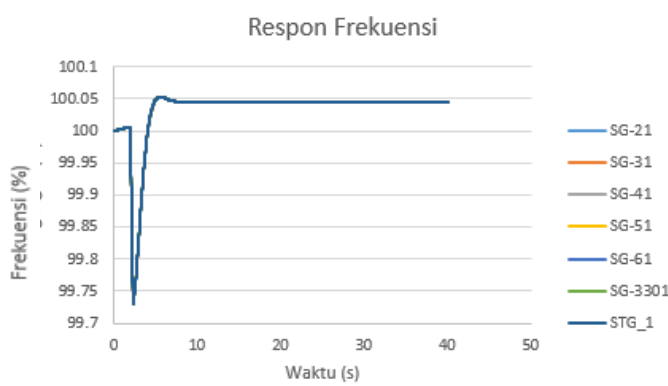

Gambar 4. Respon Frekuensi Saat Generator P-2 Outage dari Sistem dengan mekanisme load shedding
Gambar 3 menunjukan ketika generator P-4 outage frekuensi terus menurun. Gambar 4 menunjukan setelah dilakukan mekanisme load shedding sistem masih dapat mempertahankan kestabilannya. Penurunan frekuensi terendah $99,73 \%$ dan kembali steady state pada $100,04 \%$. Berdasarkan kepada standar ANSI/IEEE C37.106-1987 [4] penurunan frekuensi yang terjadi pada studi kasus ini masih diperkenankan.

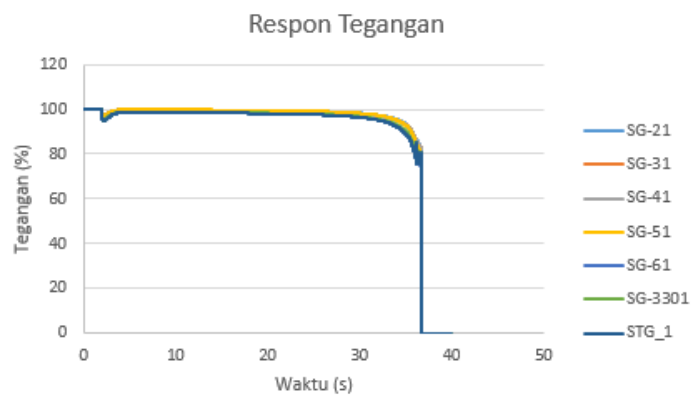

Gambar 5. Respon Tegangan Saat Generator P-4 Outage dari Sistem Respon Tegangan

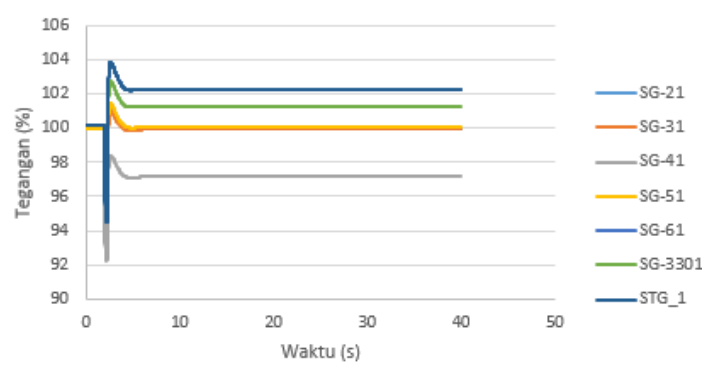

Gambar 6. Respon Tegangan Saat Generator P-4 Outage dari Sistem dengan mekanisme load shedding

Gambar 5 menunjukkan ketika generator P-4 outage tegangan pada masing-masing bus terus turun. Gambar 6 menunjukkan tegangan pada masing-masing bus setelah dilakukan mekanisme load shedding, penurunan tegangan berada pada $90,86 \%$ - 96,23\%. Kemudian sistem kembali stabil nilai tegangan antara 99,93\% - 102,26\%.

\section{B.2 Studi kasus CASE B, Gen STG off}

Pada kasus ini disimulasikan case B (STG terhubung) lepasnya generator STG dan dilanjutkan mekanisme load shedding.

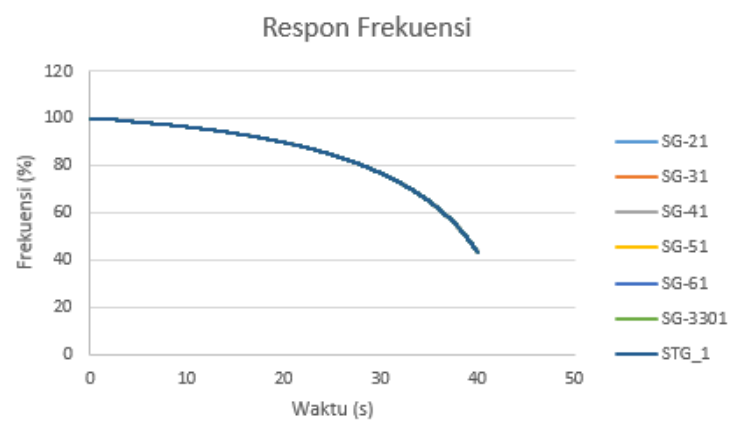

Gambar 7. Respon Frekuensi Saat Generator STG Outage dari Sistem 


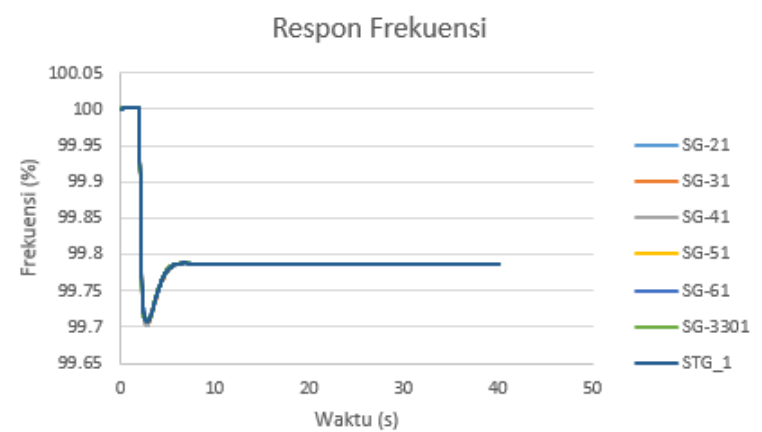

Gambar 8. Respon Frekuensi Saat Generator STG Outage dari Sistem dengan mekanisme load shedding

Gambar 7 menunjukan ketika generator STG outage frekuensi terus menurun. Gambar 8 menunjukan setelah dilakukan mekanisme load shedding sistem masih dapat mempertahankan kestabilannya. Penurunan frekuensi terendah $99,70 \%$ dan kembali steady state pada $99,78 \%$. Berdasarkan kepada standar ANSI/IEEE C37.106-1987 [4] penurunan frekuensi yang terjadi pada studi kasus ini masih diperkenankan.

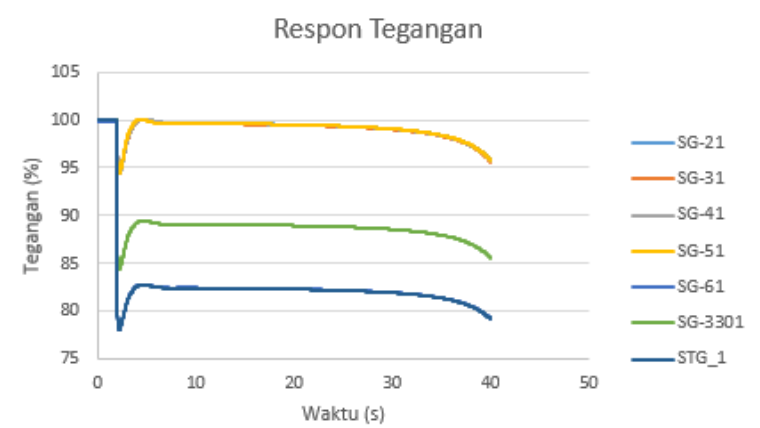

Gambar 9. Respon Tegangan Saat Generator STG Outage dari Sistem

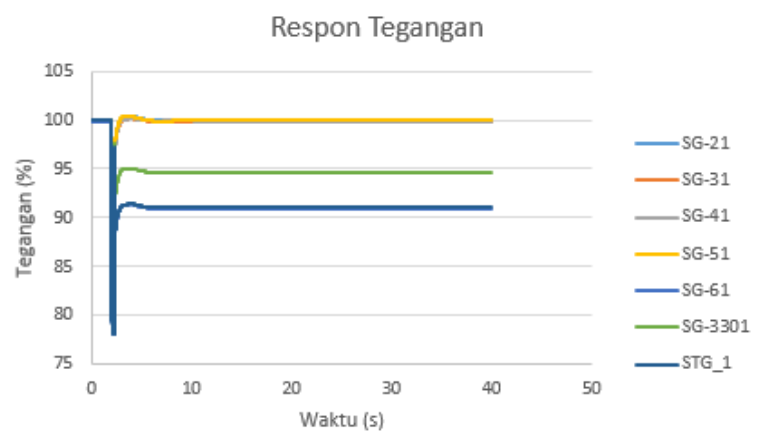

Gambar 10. Respon Tegangan Saat Generator STG Outage dari Sistem dengan mekanisme load shedding

Gambar 9 menunjukkan ketika generator STG outage tegangan pada masing-masing bus terus turun. Gambar 10 menunjukkan tegangan pada masing-masing bus setelah dilakukan mekanisme load shedding, penurunan tegangan berada pada $78,12 \%$ - 94,50\%. Kemudian sistem kembali stabil nilai tegangan antara 90,93\% - 99,92\%.

\section{Simulasi Short Circuit}

Simulasi kestabilan transien untuk studi kasus ketika terjadi short circuit pada Bus STG_1

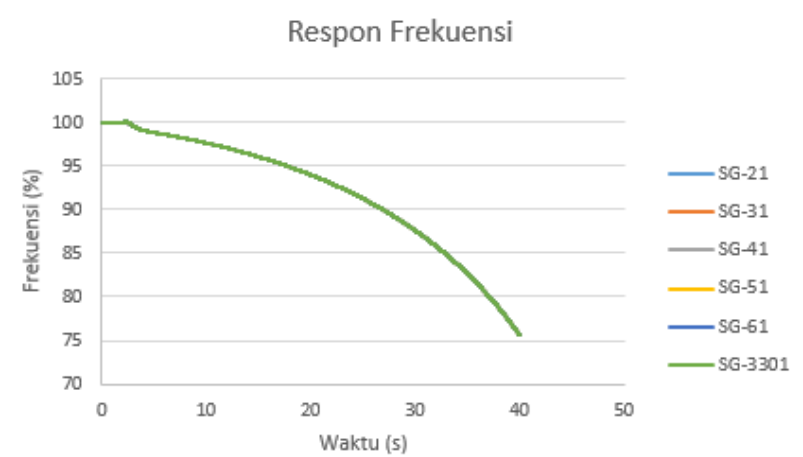

Gambar 11. Respon Frekuensi Saat Terjadi Gangguan Hubung Singkat di Bus STG_1

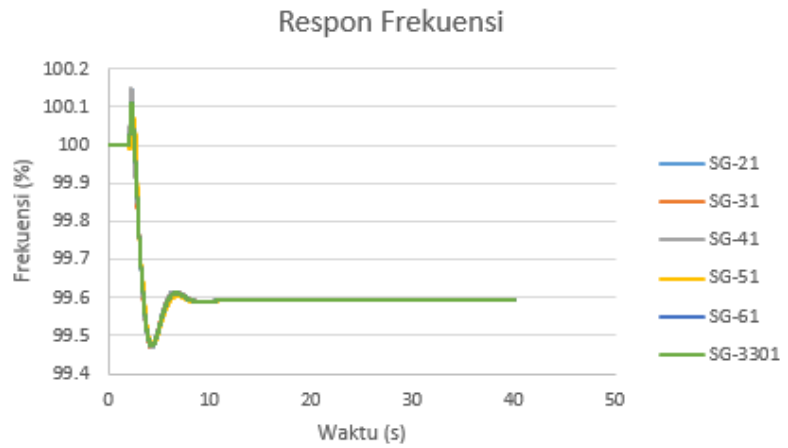

Gambar 12. Respon Frekuensi Saat Terjadi Gangguan Hubung Singkat di Bus STG_1 dengan mekanisme load shedding

Gambar 11 menunjukan saat terjadi gangguan hubung singkat di bus STG_1 frekuensi terus menurun. Gambar 12 menunjukan setelah dilakukan mekanisme load shedding sistem masih dapat mempertahankan kestabilannya. Penurunan frekuensi terendah $99,47 \%$ dan kembali steady state pada 99,59\%. Berdasarkan kepada standar ANSI/IEEE C37.106-1987 [4] penurunan frekuensi yang terjadi pada studi kasus ini masih diperkenankan.

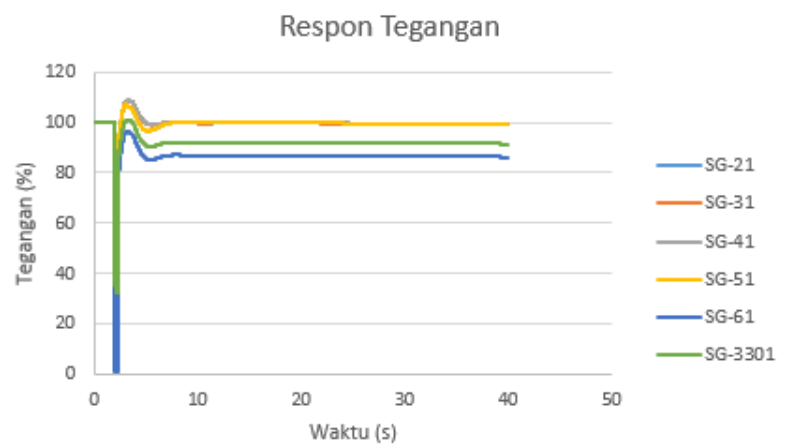

Gambar 13. Respon Tegangan Saat Saat Terjadi Gangguan Hubung Singkat di Bus STG_1

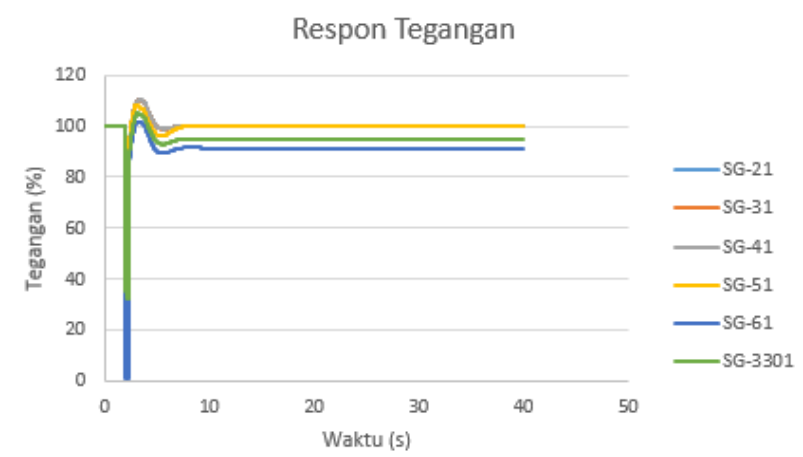

Gambar 14. Respon Tegangan Saat Terjadi Gangguan Hubung Singkat di Bus STG_1 dengan mekanisme load shedding 
Gambar 13 menunjukan tegangan saat terjadi gangguan hubung singkat di bus STG_1 masih sedikit berosilasi. Gambar 14 menunjukkan tegangan pada masing-masing bus setelah dilakukan mekanisme load shedding, penurunan tegangan berada pada $0,79 \%-78,82 \%$. Kemudian sistem kembali stabil nilai tegangan antara 91,35\% - 99,87\%. Kondisi tegangan sistem setelah dilakukan meknisme Load Shedding pada saat studi kasus ini masih diperkenankan. Dengan kondisi koil kontaktor CB tidak dihubungkan dengan bus secara langsung melainkan dihubungkan dengan UPS atau sumber lain dan mengubah setting relay undervoltage menjadi lebih lama $0,2 \mathrm{~s}$ dari sebelumnya.

\section{Simulasi Motor Starting}

Simulasi kestabilan transien untuk studi kasus ketika terjadi starting motor dengan kapasitas yang terbesar. Pada kasus ini akan disimulasikan, motor dengan ID 101-J1' yang berkapasitas $2200 \mathrm{~kW}$ starting dengan metode direct-online.

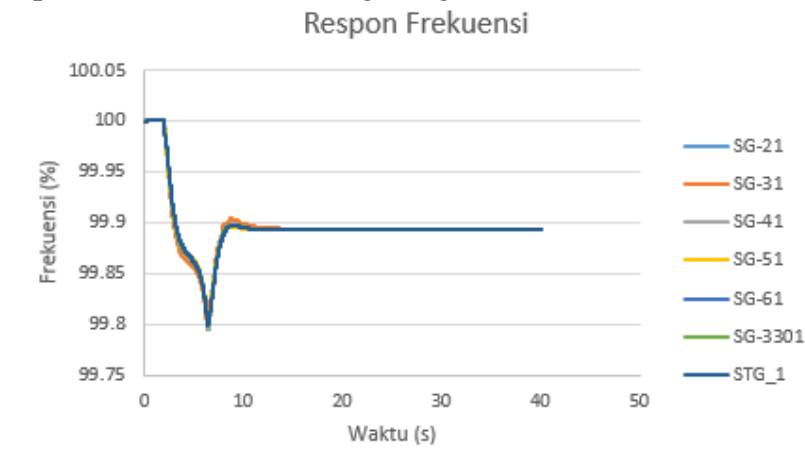

Gambar 15. Respon Frekuensi Saat Starting Motor 101-J1'

Gambar 15 menunjukkan bahwa respon frekuensi bus pada saat 101-J1' start pada $\mathrm{t}=2 \mathrm{~s}$. Dari gambar menunjukkan bahwa frekuensi bus pada masing-masing level tegangan mengalami penurunan, akan tetapi sistem masih dapat mempertahankan kestabilannya. Penurunan frekuensi terendah mencapai 99,79\% pada detik ke 6,3 s. Sistem kembali steady state pada 99,89\% dari frekuensi normal. Berdasarkan kepada standar ANSI/IEEE C37.1061987 [4] osilasi frekuensi yang terjadi pada studi kasus ini masih diperkenankan.

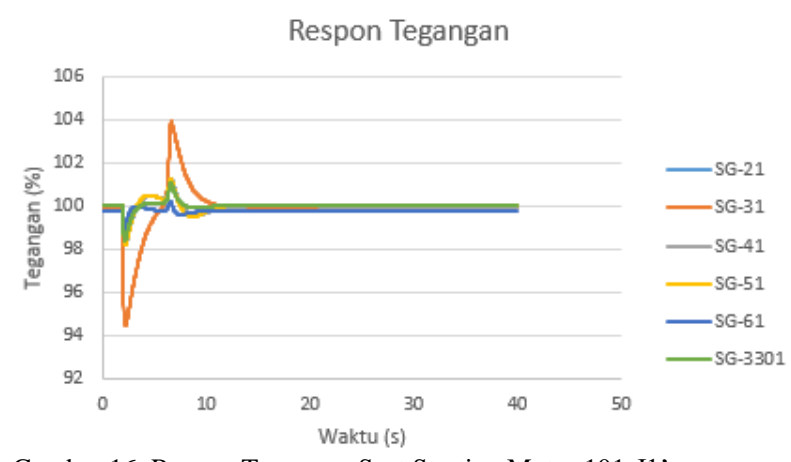

Gambar 16. Respon Tegangan Saat Starting Motor 101-J1'

Gambar 16 menunjukkan respon tegangan masingmasing bus pada saat 101-J1' start pada $\mathrm{t}=2 \mathrm{~s}$. Bus SG-21 mengalami penurunan tegangan hingga $98,30 \%$ dan kembali stabil pada $99,98 \%$. Bus SG-31 mengalami penurunan tegangan hingga $94,44 \%$ dan kembali stabil pada $99,92 \%$. Bus SG-41 mengalami penurunan tegangan hingga 98,27\% dan kembali stabil pada 99,97\%. Bus SG-51 mengalami penurunan tegangan hingga $98,17 \%$ dan kembali stabil pada 99,98\%. Bus SG-61 mengalami penurunan tegangan hingga
98,77\% dan kembali stabil pada 99,76\%. Bus SG-3301 mengalami penurunan tegangan hingga 98,38\% dan dan kembali stabil pada $100,01 \%$. Bus STG_1 mengalami penurunan tegangan hingga 99,02\% dan dan kembali stabil pada $99,99 \%$. Dengan demikian dapat disimpulkan bahwa kondisi tegangan sistem pada saat studi kasus ini masih dalam batas aman.

\section{KESIMPULAN}

Berdasarkan hasil yang diperoleh dari simulasi dan analisis pada penelitian ini, dapat diambil beberapa kesimpulan sebagai berikut:

a) Dari 9 kasus lepasnya pembangkit sebelum dilakukan mekanisme load shedding dapat menyebabkan kondisi sistem kelistrikan yang berbahaya, yaitu 1 kasus menyebabkan underfrequency dan 5 kasus lainnya menyebabkan terjadi underfrequency dan undervoltage.

b) Dari 4 kasus hubung singkat pada plant baru didapatkan bahwa kasus $S C 1$ (SG-3301) $33 \mathrm{kV}, S C 2$ (SG-SB) $13,8 \mathrm{kV}$, dan SC 4 (STG-1) 13,8 mengakibatkan sistem menjadi tidak stabil, sehingga tidak didapat kondisi steady state. Sedangan pada kasus SC 3 (SG-61) menunjukkan bahwa respon tegangan, frekuensi, dan sudut rotor tetap stabil. Nilai tegangan antara 100,04\%$100,42 \%$, frekuensi $100,81 \%$, dan sudut rotor berosilasi namun simpangannya tidak melebihi 90 derajat dan dapat stabil kembali. Nilai tersebut masih dalam batas standar yang diizinkan sehingga sistem masih aman.

c) PT. Pusri Palembang sangat handal dalam hal starting motor. Penyalaan motor $2200 \mathrm{~kW}$ secara direct online saat 5 generator $O N$ masih diizinkan karena tegangan dan frekuensi hanya mengalami penurunan yang sangat kecil. Penurunan frekuensi $0,10 \%$ dan penurunan tegangan $5,48 \%$ dari kondisi steady state serta sudut rotor mengalami sedikit osilasi namun masih dalam batas standar aman.

Saran yang dapat diberikan untuk memperbaiki sistem setelah melakukan anlisis adalah sebagai berikut:

a) Sebaiknya dalam perancangan pelepasan beban, bebanbeban yang dilepas harus di dekat generator yang mengalami kasus outage/lepas.

b) Untuk beberapa kasus lepasnya unit pembangkit yang mengakibatkan nilai tegangan bus mengalami penurunan hingga kurang dari $80 \%$, perlu dilakukan setting rele pengaman (undervoltage relay) dengan delay waktu minimal sebesar total durasi waktu saat tegangan bus kurang dari $80 \%$ pada saat terjadi gangguan.

c) Untuk kasus hubung singkat SC 1 (SG-3301) $33 \mathrm{kV}, \mathrm{SC}$ 2 (SG-SB) 13,8kV, SC 3 (SG-61) dan SC 4 (STG-1) 13,8, saran kedepannya, nilai dari kedip tegangan (voltage sag) lebih diperhatikan agar tidak mempengaruhi kerja dari peralatan-peralatan elektronik atau peralatan control dalam pabrik/industri.

d) Untuk kasus hubung singkat SC 1 (SG-3301) $33 \mathrm{kV}, \mathrm{SC}$ 2 (SG-SB) 13,8kV, SC 3 (SG-61) dan SC 4 (STG-1) 13,8, perlu dilakukan setting rele pengaman (undervoltage relay) dengan delay waktu minimal sebesar total durasi waktu saat tegangan bus kurang dari $80 \%$ pada saat terjadi gangguan. Kontaktor circuit breaker dihubungkan dengan UPS atau sumber lain, tidak disarankan dihubungkan langsung dengan bus. 


\section{DAFTAR PUSTAKA}

[1] Grigsby, Leonard., "Power System Stability and Control, 3rd edition", CRC Press, Taylor and Francis Group, 2012.

[2] IEEE/CIGRE Joint Task Force on Stability Terms and Definitions, "Definition and Classification of Power System Stability"IEEE Transactions on Power system, vol. 19, no. 2, may 2004.

[3] Kundur, Prabha, "Power System Stability and Control", McGrawHill Companies Inc, 1994.

[4] IEEE, "Guide for Abnormal Frequency Protection for Power Generating Plants", 1987. IEEE Std. C37.106-2003(Revision of ANSI/IEEE C37.106-1987). 